\title{
Pengaruh Tes Potensi Akademik Siswa Terhadap Prestasi Belajar
} Matematika

\author{
Ganjar Susilo $^{1}$, \& Tri Astuti Nur'aini² \\ Universitas Balikpapan
}

\section{INFO ARTICLES}

\section{Article History:}

Received: $17-11-2018$

Revised: 05-12-2018

Approved: 08-12-2018

Publish Online: 30-12-2018

\section{Key Words:}

test academic potential, learning achievement, mathematics

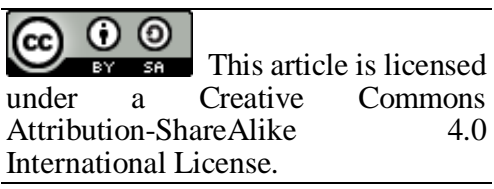

\footnotetext{
Correspondence Address: Universitas Balikpapan, Jalan Pupuk Raya, Gunung Bahagia, Balikpapan Selatan, Kalimantan Timur, 76114; email: ganjar.susilo@uniba-bpn.ac.id

How to Cite (APA $6^{\text {th }}$ Style): Susilo dan Nur'aini (2018). Pengaruh Test Potensi Akademik Terhadap Prestasi Belajar Matematika. JKPM (Jurnal Kajian Pendidikan Matematika), Vol. 4 (1), 21-28.
}

Copyright: Susilo, G., Nur”aini, T.A, (2018)

Competing Interests Disclosures: The authors declare that they have no significant competing financial, professional or personal interests that might have influenced the performance or presentation of the work described in this manuscript.

\begin{abstract}
Abstrak: Tujuan penelitian ini untuk mengetahui pengaruh tes potensi akademik siswa terhadap prestasi belajar matematika. Penelitian ini dilaksanakan pada siswa kelas XI SMA Negeri se-Kabupaten Kutai Kartanegara Tahun Pelajaran 2018/2019. Teknik pengambilan sampel menggunakan stratified cluster random sampling yang berdasarkan nilai rata-rata ujian nasional mata pelajaran matematika tahun pelajaran 2017/2018. Pada sekolah kategori atas, terpilih SMA Negeri 3 Unggulan Tenggarong, sekolah kategori sedang terpilih SMA Negeri 1 Samboja dan SMA Negeri 1 Muara data menggunakan analisis regresi ganda. Berdasarkan hasil penelitian diperoleh terdapat pengaruh tes potensi akademik dengan prestasi belajar matematika siswa SMA Negeri Kelas XI di Kabupaten Kutai Kartanegara.
\end{abstract}




\section{PENDAHULUAN}

Tes merupakan suatu alat uji atau instrumen uji dalam dunia pendidikan yang sangat penting, karena tes pada hakikatnya adalah serangkaian pertanyaan atau tugas yang harus dijawab atau dikerjakan oleh siswa yang hasilnya digunakan untuk mengukur kemampuan siswa. Sebagai alat pengukuran dalam evaluasi, tes memberikan data kuantitaif. Adanya sebuah tes dapat menjadikan sebagai ukuran keberhasilan baik pada proses pembelajaran suatu pendidikan. Pada dasarnya pelaksanaan tes biasa dilakukan pada sebelum proses pembelajaran yang sering dikenal sebagai pretest atau tes yang dilakukan pada akhir proses pembelajaran yang sering disebut sebagai posttest. Tujuan tes dalam pembelajaran adalah menyediakan informasi yang akurat mengenai tingkat pencapaian dalam proses pembelajaran, sehingga dapat diambil keputusan menganai tindak lanjut apa yang harus dilakukan terhadap siswa. Selama ini sekolah di jenjang menengah atas atau SMA belum pernah mengadakan tes potensi akademik (TPA) sebagai penentuan penjurusan siswa ke kelas bidang ilmu pengetahuan alam (IPA) atau ke kelas bidang ilmu pengetahuan sosial (IPS). Menurut Riswanto (2013) tes potensi akademik adalah suatu tes yang diadakan untuk mengukur kemungkinan keberhasilan siswa dalam menjalani mata pelajaran yang akan di pelajari di kelas. Materi yang terdapat pada tes potensi akademik terdiri atas 3 (tiga) subtes yaitu tes verbal, kuantitatif dan penalaran. Tes verbal berisi tes persamaan kata, tes lawan kata, dan analogi verbal, untuk tes kuantitatif berisi tes angka, tes seri, tes aritmatika, dan logika aritmatika, sedangkan untuk tes penalaran berisi tes logika formal, analitis, keruangan/spasial, dan penalaran logis.

Azwar (2008) mengungkapkan dengan adanya tes potensi akademik ini jika siswa mampu dengan baik mengerjakan tes potensi akademik yang terdiri dari tes verbal, kuantitatif, dan penalaran maka tingkat keberhasilan siswa dalam mengikuti pelajaran yang akan ditempuhnya minimal akan sangat baik dalam mengikuti dan menguasai mata pelajaran yang disajikan guru terutama pelajaran matematika. Hal ini disebabkan konten soal-soal dalam tes potensi akademik dikembangkan sedemikian rupa sehingga peluang keberhasilan untuk menjawab dengan benar lebih bergantung pada penggunaan daya nalar baik logis ataupun analitik (menghitung). Menurut Widhiarso (2016) manfaat tes potensi akademik ini adalah sebagai gambaran siswa untuk mencapai kesuksesan dalam mata pelajaran yang ditempuh disekolah, menilai kemampuan siswa dalam menganalisis dan menyelesaikan sebuah persoalan, dan sebagai prediktor kesuksesan siswa dalam belajar di sekolah. Berdasarkan informasi yang diperoleh peneliti di salah satu sekolah menengah atas (SMA) yang berada di Kabupaten Kutai Kartanegara yaitu SMA Negeri di Kecamatan Samboja mengungkapkan bahwa tes potensi akademik tidak pernah dilakukan dalam upaya penjurusan siswa-siswa yang ditempatkan di kelas IPA maupun IPS. Untuk menentukan siswa yang masuk kelas IPA dan IPS pihak sekolah menjuruskan siswa-siswanya hanya berdasarkan dari hasil nilai rapor setelah menempuh satu tahun pelajaran. Akibatnya banyak siswa yang merasa senang dengan ilmu pengetahuan sosial (IPS) masuk kedalam kelas ilmu pengetahuan Alam (IPA) yang mengakibatkan sebagian prestasi belajar siswa menurun terutama pada nilai mata pelajaran matematika. Mata pelajaran matematika selama ini masih menjadi mata pelajaran yang sulit untuk mendapat prestasi belajar siswa yang terbaik, hal ini didasari oleh data dari Litbang Kemendikbud tentang Laporan Hasil Ujian Nasional Tahun 2014/2015 untuk wilayah Kabupaten Kutai Kartanegara rata-rata nilai UN untuk mata pelajaran matematika diperoleh 51,53 hal ini masih dibawah nilai rata-rata nilai UN tingkat nasional yaitu 60,35.

Oleh karena itu penting sekali bagi sekolah untuk mengadakan tes potensi akademik secara berkelanjutan sebagai tolok ukur siswa dalam mencapai kesuksesan belajar terutama mata pelajaran matematika bagi siswa SMA yang berada di kelas bidang IPA dan IPS di Kabupaten Kutai Kartanegara. Selain itu pula, dalam penelitian ini akan dideskripsikan seberapa besar pengaruh tes potensi akademik siswa 
terhadap prestasi belajar matematika pada kelas IPA dan IPS SMA Negeri di Kabupaten Kutai Kartanegara Tahun Pelajaran 2018/2019.

\section{METODE}

Penelitian ini menggunakan metode penelitian kuantitatif dengan mengkaji hubungan tes potensi akademik siswa SMA Negeri di Kabupaten Kutai Kartanegara terhadap prestasi belajarnya. Uji statistik yang digunakan adalah analisis regresi linier sederhana karena dalam penelitian ini akan menunjukkan kekuatan relasi (hubungan) variabel terikat dengan variabel bebas yang akan diteliti (Budiyono, 2009). Populasi target dalam penelitian ini adalah SMA Negeri di Kabupaten Kutai Kartanegara sebanyak 30 unit. Teknik pengambilan sampel menggunakan teknik stratified cluster random sampling Tekniknya dengan membedakan populasi menjadi tiga kategori peringkat sekolah berdasarkan nilai rata-rata ujian nasional mata pelajaran matematika tahun pelajaran 2017/2018. Setelah dibedakan menjadi tiga kategori peringkat sekolah yaitu atas, sedang, dan bawah. Selanjutnya dilakukan pengundian untuk memilih tiga sekolah dengan cara mengambil satu sekolah dari tiap-tiap kategori yang akan dijadikan tempat penelitian. Pada sekolah kategori atas, terpilih SMA Negeri 3 Unggulan Tenggarong, sekolah kategori sedang terpilih SMA Negeri 1 Samboja dan SMA Negeri 1 Muara Jawa, sekolah kategori bawah terpilih SMA Negeri 1 Sangasanga. Teknik pengumpulan data menggunakan metode dokumentasi dan tes potensi akademik siswa yang terdiri dari 100 butir soal. Teknik analisis data untuk melihat pengaruh tes potensi akademik siswa terhadap prestasi belajar siswa kelas XI SMA se-Kabupaten Kutai Kartanegara adalah analisis regresi sederhana dengan uji $t$ dengan terlebih dahulu diuji asumsi klasik regresi sederhana yaitu uji normalitas, uji linieritas, dan uji heterokedastisitas.

\section{HASIL}

Penelitian pendahuluan dilakukan untuk mengetahui daftar sekolah menengah atas (SMA) Negeri di Kabupaten Kutai Kartanegara yang diperoleh dari Diknas Pendidikan Provisi Kalimantan Timur. Data yang diperoleh adalah daftar nilai ujian nasional (UN) Tahun Ajaran 2017/2018 dari 30 sekolah menengah atas (SMA) Negeri se-Kabupaten Kutai Kartanegara. Daftar Sekolah tersebut dapat dilihat pada lampiran 4. Sekolah yang dijadikan tempat penelitian berdasarkan kategori peringkat nilai ujian nasional sebagai berikut.

1) Sekolah dengan peringkat nilai ujian nasional tertinggi adalah SMA Negeri 3 Unggulan Tenggarong dengan skor 54,41.

2) Sekolah dengan peringkat nilai ujian nasional sedang adalah SMA Negeri 1 Samboja dengan skor 30,52 dan SMA Negeri 1 Muara Jawa degan skor 30,48.

3) Sekolah dengan peringkat nilai ujian nasional terendah adalah SMA Negeri 1 Sangasanga dengan skor 29,21 .

Dalam penelitian ini akan digunakan 100 butir soal tes potensi akademik (TPA) yang memiliki indikator tes verbal, tes kuantitatif, dan tes penalaran. Pembuatan tes potensi akademik (TPA) bekerja sama dengan Lembaga Terapan Psikologi Pengembangan Sumber Daya Manusia (LTPPSDM) Universitas Balikpapan. Kemudian tes potensi akademik ini di terapkan ke sekolah-sekolah yang telah ada pada sampel penelitian. Selanjutnya untuk data prestasi belajar matematika diperoleh dari rata-rata nilai ulangan harian siswa yang telah dilakukan oleh guru pada sekolah yang dijadikan sampel penelitian yaitu siswa SMA kelas XI di SMA Negeri 3 Tenggarong, SMA Negeri 1 Muara Jawa, SMA Negeri 1 Samboja, dan SMA Negeri 1 Sangasanga. 
Deskripsi data penelitian dilakukan untuk menggambarkan variabel tes potensi akademik (TPA) siswa dan variabel prestasi belajar matematika siswa SMA Negeri di Kabupaten Kutai Kartanegara. Kedua variabel tersebut akan dianalisis dan selanjutnya hasil analisis tersebut dapat digunakan untuk menjawab rumusan masalah penelitian. Berikut Tabel Deskripsi Statistika Penelitian.

Tabel 1. Deskripsi Statistika Penelitian

\begin{tabular}{cccc}
\hline Variabel Penelitian & Mean (Rata-rata) & $\begin{array}{l}\text { Std.Deviation (Deviasi } \\
\text { Standar) }\end{array}$ & $\begin{array}{c}\text { N } \\
\text { (Banyak Sampel) }\end{array}$ \\
\hline $\begin{array}{c}\text { Prestasi Belajar Matematika } \\
\text { Siswa }\end{array}$ & 60,4898 & 15,12339 & 242 \\
\hline $\begin{array}{c}\text { Hasil Tes Potensi Akademik } \\
\text { (TPA) }\end{array}$ & 46,940 & 13,089 & 242 \\
\hline
\end{tabular}

Sumber: Diolah dari data penelitian, 2018

Berdasarkan tabel 1 dapat diketahui bahwa rata-rata prestasi belajar matematika 60,489 dengan deviasi standar 15,12339 dan banyak datanya adalah 242. Kemudian untuk hasil tes potensi akademik (TPA) memiliki rata-rata 46,940 dengan deviasi standar 13,089 dan banyak datanya adalah 242. Selanjutnya setelah semua data yang dibutuhkan terkumpul, data tersebut kemudian harus memenuhi uji prasyarat analisis regresi linier sederhana yaitu uji normalitas, uji linieritas dan uji heteroskedastisitas. Berikut hasil dari uji prasayarat regresi linier sederhana.

Pengujian ini dilakukan dengan menggunakan uji Kolmogorov-smirnov dengan taraf signifikansi 0,05. Hasil uji normalitas pada variabel penelitian ini adalah sebagai berikut:

Tabel 2. Hasil Uji Normalitas

\begin{tabular}{lccccc}
\hline \multicolumn{1}{c}{ Variabel } & $\alpha$ & N & Sig. & Keptusan & Simpulan \\
\hline $\begin{array}{l}\text { Residu variabel tes kompotensi } \\
\text { akademik (TPA) terhadap prestasi } \\
\text { belajar matematika }\end{array}$ & 0,05 & 242 & 0,051 & $\begin{array}{c}\text { Karena nilai sig. } \geq 0,05, \\
\text { maka } \mathrm{H}_{0} \text { diterima }\end{array}$ & $\begin{array}{c}\text { residual data } \\
\text { berdistribusi normal }\end{array}$ \\
\hline
\end{tabular}

Sumber: Diolah dari data Penelitian, 2018

Berdasarkan hasil uji normalitas data diperoleh nilai signifikan sebesar 0,051. Karena nilai signifikan lebih dari 0,05 atau 0,051>0,05 maka residual variabel tes kompotensi akademik (TPA) terhadap prestasi belajar matematika berdistribusi normal. Uji liniearitas dalam penelitian ini dilakukan antara masing-masing variabel bebas dengan variabel terikat terjadi linier atau tidak. Dikatakan linier jika nilai signifikan pada masing-masing variabel bebas lebih besar dari 0,05 atau nilai signifikan $>0,05$. Berikut hasil analisis uji linieritas:

Tabel 3. Hasil Uji Linieritas

\begin{tabular}{|c|c|c|c|c|c|}
\hline & & & df & $\mathrm{F}$ & Sig. \\
\hline Prestasi Belajar Matematika & Between Groups & (Combined) & 51 & 1,589 & 0,014 \\
\hline \multirow[t]{4}{*}{ Siswa*Hasil TPA } & & Liniearity & 1 & 29,752 & 0,000 \\
\hline & & Deviation from Liniearity & 50 & 1,026 & 0,438 \\
\hline & Within Groups & & 190 & & \\
\hline & Total & & 241 & & \\
\hline
\end{tabular}

Sumber: Diolah dari data penelitian, 2018

Dari tabel 3 dapat diketahui bahwa dilihat pada baris Deviation from Liniearity, yakni $\mathrm{F}_{\mathrm{obs}}=1,026$ dan pada baris yang sama terlihat nilai Sig. (nilai probabilitas) $=0,438$. Karena taraf signifikansi $\alpha=0,05$ dan nilai Sig. $=0,438>0,05$, maka $\mathrm{H}_{0}$ diterima, sehingga terdapat hubungan antara variabel tes potensi akademik (X) dan variabel prestasi belajar matematika (Y) adalah linier. Uji heteroskedastisitas dimaksudkan untuk mendeteksi gangguan yang diakibatkan faktor-faktor dalam model tidak memiliki 
varians yang sama. Model regresi yang baik adalah model regresi yang homokedastisitas atau model regresi tersebut tidak terjadi heteroskedastisitas.

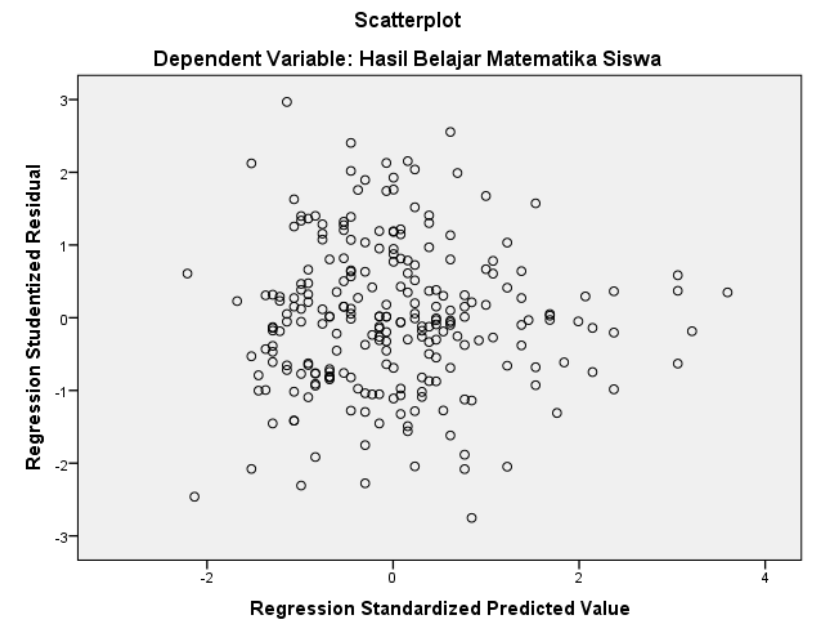

Gambar 1. Scatter Plot Uji Heteroskedastisitas

(Sumber: Diolah dari data Penelitian, 2018)

Pengujian heteroskedastisitas dilakukan dengan menggunakan scatter plot. Jika tiadk terdapat pola tertentu menunjukkan bahwa model regresi tersebut bebas dari masalah heteroskedastisitas. Pada gambar 1 menujukkan bahwa titik tampak random dan tidak membentuk pola tertentu. Oleh karena itu, dapat dinyatakan bahwa model regresi tersebut homogen atau bebas dari gejala heteroskedastisitas. Data yang dianalisis diperoleh dari data tes potensi akademik dan prestasi belajar matematika siswa kelas XI SMA Negeri di Kabupaten Kutai Kartanegara dengan menggunakan persamaan linier sederhana untuk mengukur besarnya pengaruh tes potensi akademik siswa terhadap prestasi belajar matematika. Berdasarkan perhitungan diperoleh nilai diperoleh nilai $\mathrm{a}=42,520$ dan $\mathrm{b}=0,383$. Sehingga estimasi model hubungan antara tes potensi akademik (X) dengan prestasi belajar matematika siswa (Y) sebagai berikut.

$$
\widehat{\mathrm{Y}}=42,520+0,383 \mathrm{X}
$$

Keterangan:

$\widehat{Y} \quad$ : prestasi belajar matematika siswa

$\mathrm{X}$ : tes potensi akademik siswa

Persamaan regresi ini dapat dijadikan sebagai prediksi untuk mengetahui pengaruh tes potensi akademik terhadap prestasi belajar matematika siswa. Nilai konstanta $(\widehat{Y})$ sebesar 42,520 yang artinya adalah jika tes kemampuan akademik siswa sama dengan nol, maka prestasi belajar matematika siswa akan menjadi 42,520. Pada nilai koefisien regresi X ( tes potensi akademik) dari perhitungan regresi sederhana diperoleh $\mathrm{b}=0,383$. Hal ini berarti setiap ada peningkatan satu poin tes potensi akademik siswa (X), maka akan diikuti kenaikan prestasi belajar matematika siswa (Y) sebesar 0,383. Karena nilai koefisien regresi bernilai positif $(+)$, maka dapat dikatakan bahwa tes kemampuan akademik berpengaruh positif terhadap prestasi belajar matematika siswa. Dari hasil analisis regresi ganda didapat juga koefisien determinasi. Koefisien determinasi dilakukan untuk mengetahui seberapa besar nilai persentase konstribusi variabel bebas tes potensi akademik (TPA) terhadap variabel terikat yaitu prestasi belajar matematika siswa. Dari hasil perhitungan didapatkan nilai koefisien determinasi sebagai berikut. 
Tabel 4. Uji Koefisien Determinasi

\begin{tabular}{rlrrr}
\hline Model & $\mathrm{R}$ & $\mathrm{R}$ Square & Adjusted $R$ Square & Std. Error of the Estimate \\
\hline 1 & $0,331^{\mathrm{a}}$ & 0,110 & 0,106 & 14,29889
\end{tabular}

a. predictors: (Constant), Hasil TPA

(Sumber: Diolah dari data Penelitian, 2018)

Dari Tabel 4, dapat diketahui nilai koefisien determinasi ( $R$ Square) sebesar 0,034. Besarnya angka koefisien determinasi 0,110 sama dengan 11\%. Angka tersebut mengandung arti bahwa tes potensi akademik berpengaruh terhadap prestasi belajar matematika sebesar 11\%. Sedangkan sisanya sebesar $100 \%$ - 11\% = 89\% dipengaruhi variabel lain di luar model regresi ini. Uji keberartian koefisien regresi digunakan untuk menguji signifikansi/keberartian regresi. Koefisien regresi dikatakan signifikan/berarti jika nilainya tidak nol. Hasil analisis uji t sebagai berikut:

Tabel 5. Hasil Uji t

\begin{tabular}{|c|c|c|c|c|c|c|}
\hline \multirow{2}{*}{\multicolumn{2}{|c|}{ model }} & \multicolumn{2}{|c|}{ Unstandardized Coefficients } & \multirow{2}{*}{$\begin{array}{c}\text { Standardized Coefficients } \\
\text { Beta }\end{array}$} & \multirow{2}{*}{$t$} & \multirow{2}{*}{ Sig. } \\
\hline & & B & Std. Error & & & \\
\hline 1 & (Constant) & 45,520 & 3,429 & & 12,401 & 0,000 \\
\hline & Hasil TPA & 0,383 & 0,070 & 0,331 & 5,440 & 0,000 \\
\hline
\end{tabular}

a. Dependent Variable: Hasil Belajar Matematika Siswa

(sumber: Lampiran 7)

Berdasarkan tabel 5 dapat diketahui pada kolom $t$ dan baris Hasil TPA terlihat nilai $t$ hitung $=5,440$. Selanjutnya pada kolom Sig. baris kedua terlihat angka 0,000. Ini berarti, dengan menggunakan taraf signifikansi $(\alpha)=0,05$ maka $\mathrm{H}_{0}$ ditolak. Jadi dapat dikatakan bahwa terdapat pengaruh tes potensi akademik dengan prestasi belajar matematika siswa SMA Negeri Kelas XI di Kabupaten Kutai Kartanegara.

\section{PEMBAHASAN}

Tes potensi akademik (TPA) merupakan suatu kegiatan yang diadakan untuk mengukur keberhasilan siswa dalam belajar. Bagi para siswa tes potensi akademik ini berfungsi sebagai panduan siswa nanti dalam menghadapi beban belajar yang ada di sekolah lanjutan, misal siswa SD yang akan melanjutkan ke SMP. Tes ini dimaksudkan untuk mengukur kemampuan abilitas kognitif potensial umum (pengukuran performansi maksimal) yang dirancang khusus untuk memprediksi keberhasilan siswa dalam belajar (Azwar, 2008). Sedangkan prestasi belajar merupakan gambaran hasil belajar siswa dalam kemampuan mengelola dan melaksanakan tugas belajar yang diberikan di oleh guru di sekolah (Gultom \& Bukit, 2013). Tes potensi akademik dan prestasi belajar matematika merupakan suatu hal yang sangat berkaitan, dikarenakan dalam pembelajaran matematika siswa dituntut dengan adanya menalar suatu kalimat logika kemudian diolah menjadi angka dan logika angka. Penelitian ini dilaksanakan di SMA Negeri se-Kabupaten Kutai Kartanegara yang dibagi menjadi 3 (tiga) kelompok sekolah kategori tinggi, sedang, dan rendah dalam mendapatkan skor Rata-rata Ujian Nasional Tahun Pelajaran 2017/2018. Pada sekolah kategori tinggi diperoleh SMA Negeri 3 Tenggarong, sekolah kategori sedang diperoleh SMA Negeri 1 Samboja dan SMA Negeri 1 Muara Jawa, serta sekolah kategori rendah adalah SMA Negeri 1 Sangasanga.

Total siswa pada penelitian ini adalah 242 siswa kelas XI SMA Negeri se-Kabupaten Kutai Kartanegara. Data yang diambil dalam penelitian ini adalah data tes potensi akademik (TPA) dan nilai hasil ulangan harian matematika siswa kelas XI SMA Negeri se-Kabupaten Kutai Kartanegara yang disesuaikan dengan tujuan penelitian yaitu mengetahui pengaruh tes potensi akademik siswa terhadap prestasi belajar matematika pada kelas IPA dan IPS SMA Negeri di Kabupaten Kutai Kartanegara Tahun Pelajaran 2018/2019. Hasil penelitian ini telah dianalisis dengan regresi linier sederhana dengan menggunakan uji t 
untuk menjawab rumusan masalah pada penelitian ini. Sebelum dilakukan uji analisis sederhana peneliti melakukan uji asumsi klasik pada analisis regresi sederhana yaitu, uji normalitas galat acak, uji linieritas untuk mengetahui hubungan variabel bebas yaitu tes potensi akademik (TPA) siswa dengan variabel terikat yaitu prestasi belajar siswa, serta uji heterokedastisitas yang digunakan untuk mengetahui model regresi terjadi ketidaksamaan variasi dari residual suatu pengamatan ke pengamatan lain.

Berdasarkan hasil analisis regresi dieproleh $\mathrm{R}$ square sebesar $11 \%$ yang berarti variabel tes potensi akademik (TPA) siswa berpengaruh terhadap prestasi belajar matematika sebesar $11 \%$ dan sisanya yaitu $100 \%-11 \%=89 \%$ dipengaruhi oleh variabel-variabel lain diluar penelitian ini. Hal ini dapat diketahui bahwa tes potensi akademik memiliki kontribusi terhadap prestasi belajar matematika di sekolah. Selain data tersebut pendukung kontribusi tes potensi akademik terhadap prestasi belajar matematika dapat terlihat pada rata-rata prestasi belajar siswa kelas XI SMA Negeri se-Kabupaten Kutai Kartanegara adalah 60,489 dan rata-rata tes potensi akademik (TPA) yaitu 46,940 dan diperoleh persamaan regresi sampel yang menggambarkan populasi yaitu $\widehat{Y}=42,520+0,383 X$. Selanjutnya nilai positif pada koefisien $X$ (variabel bebas: tes potensi akademik) yaitu 0,0383 menggambarkan bahwa arah hubungan antara variabel bebas (tes potensi akademik) dengan variabel terikat (prestasi belajar matematika) adalah searah, dimana setiap kenaikan satu satuan variabel bebas (tes potensi akademik) akan menyebabkan kenaikan pula pada prestasi belajar matematika siswa.

Berdasarkan analisis dengan menggunakan uji t diperoleh nilai sig. $=0,000<0,05$ maka $\mathrm{H}_{0}$ ditolak, sehingga dapat diketahui bahwa terdapat pengaruh antara tes potensi akademik dan prestasi belajar matematika siswa kelas XI SMA Negeri se-Kabupaten Kutai Kartanegara. Sejalan dengan hasil penelitian ini, Primartadi (2012) mengungkapkan siswa yang memiliki kemampuan akademik yang baik biasanya cukup cakap dalam proses pembelajaran dikelas, sedangkan siswa yang memiliki kemampuan akademik yang rendah akan mengakibatkan susahnya menerima materi dalam pembelajaran sehingga akan lebih sulit berkembang dan kurang kreatifitas dalam belajar di sekolah maupun dirumah. Tes potensi akademik pada penelitian ini terdiri dari tes verbal, tes kuantitatif, dan tes penalaran, dimana tes tersebut merupakan tes kesiapan pendidikan yang secara umum disebut sebagai tes kemampuan belajar yang mempunyai kegunaan sama dengan tes intelegensi serta dapat dipakai mulai dari sekolah dasar hingga sekolah tinggi(Primartadi, 2012). Sarwa (2010) mengungkapkan dengan tes potensi akademik, seorang siswa dituntut untuk mengerjakan setiap butir soal dengan kriteria sub tes pada TPA dengan tujuan untuk melihat tingkat keberhasilan dalam menempuh pelajaran yang akan dibebankan dalam proses belajar mengajar di kelas.

Perlu diketahui pula dalam penyusunan tes potensi akademik berbeda dengan tes-tes prestasi belajar yang disusun sesuai dengan silabus pembelajaran pada suatu jenjang pendidikan atau pelatihan yang lebih mengungkapkan hasil belajar. tes potensi disusun sebagai tujuan untuk mengukur keberhasilan siswa dalam menjawab soal dalam tes, minimal kaitannya dengan penguasaan isi pelajaran tertentu. Tes potensi akademik dikembangkan sedemikian rupa disusun untuk mengetahui tingkat keberhasilan seseorang menjawab soal-soal yang ada dengan menggunakan daya penalaran baik logis maupun analitis (Azwar, 2008). Berpengaruhnya tes potensi akademik dalam prestasi belajar matematika, berarti bepengaruh juga penalaran logis maupun analitis siswa dalam upaya mendapatkan pembelajaran dari guru mata pelajaran. Penalaran logis sangat dibutuhkan dalam proses belajar matematika dikarenakan dengan adanya penalaran logis siswa mampu memperhitungkan bilangan, pola, deret ataupun barisan suatu bilangan.(Epriliyanti \& Amin (2017) mengungkapkan siswa dengan kecerdasan logis matematis yang tinggi berarti siswa tersebut mampu mengoperasikan bilangan atau perhitungan dasar, dan bentuk persamaan dengan tepat dan baik. Sedangkan siswa dengan kemampuan analitis yang baik dapat membantu siswa untuk belajar dan mengenal lingkungan sekitarnya. Lingkungan disekitar siswa terdapat beberapa objek yang terkait dengan geometri seperti bentuk bola, kotak perhiasan, kaleng minuman, dan lemari. 


\section{SIMPULAN}

Kesimpulan yang diperoleh dari hasil penelitian terdapat pengaruh tes potensi akademik dengan prestasi belajar matematika siswa SMA Negeri Kelas XI di Kabupaten Kutai Kartanegara

\section{PENGHARGAAN}

Tiada kata yang pantas diucapkan melainkan memanjatkan puja dan puji syukur kehadirat Allah SWT. Karena berkat Rahmat, Hidayah dan Inayah-Nya jurnal penelitian dosen pemula telah selesai dengan baik. Selama proses penelitian dosen pemula ini, peneliti banyak sekali mendapat pengalaman berharga, nasihatnasihat dan dukungan dari berbagai pihak. Namun demikian bukan berarti tak luput dari berbagai cobaan dan rintangan yang menghadang. Pada kesempatan ini penulis mengucapkan terima kasih yang sebesarbesarnya kepada:

1. Kemenristekdikti yang telah memberikan bantuan dana untuk pendanaan penelitian tahun 2018 kepada peneliti untuk melaksanakan penelitian ini.

2. Merry K Sipahutar, S.Pi.,M.Si.,P.Hd sebagai Ketua Lembaga Penelitian dan Pengabdian Kepada Masyarakat (LPPM) atas dukungan yang diberikan.

3. Berbagai pihak yang telah membantu terlaksananya penelitian ini.

\section{DAFTAR RUJUKAN}

Azwar, S. (2008). Kualitas Tes Potensi Akademik (TPA) 07A. Jurnal Penelitian Dan Evaluasi Pendidikan, $12(2), 231-250$.

Budiyono. (2009). Statistika Untuk Penelitian (2nd ed.). Surakarta: Sebelas Maret University Press.

Epriliyanti, L. W., \& Amin, S. M. (2017). Pengaruh Kecerdasan Logis Matematis Dan Spasial-Visual Terhadap Hasil Belajar Matematika Siswa SMP. Mathedunesa Jurnal Ilmiah Pendidikan Matematika, 2(6), 123-130. Retrieved from http://jurnalmahasiswa.unesa.ac.id/index.php/mathedunesa/article/view/19746/0

Gultom, A. S., \& Bukit, N. (2013). Efek Model Pembelajaran Kooperatif Tipe Student Team Achievement Divisions dan Tes Potensi Akademik Terhadap Hasil Belajar Fisika Pada Materi Optik Geometri. Jurnal Pendidikan Fisika, 2(2).

Primartadi, A. (2012). Pengaruh Metode Student Teams-Achievement Division (STAD) Dan Problem Based Learning Terhadap Hasil Belajar Ditinjau Dari Potensi Akademik Siswa SMK Otomotif. Jurnal Pendidikan Vokasi, 2(1), 143-153. https://journal.uny.ac.id/index.php/jpv/article/view/1024

Riswanto, I. (2013). Pengembangan Soal Tes Potensi Akademik Numerik Penerimaan Siswa Baru SMP Berbantuan Media Berbasis Wireless Application Protocol Java 2 Micro Edition (J2ME). Jurnal Pancaran Pendidikan, 2(1), 95-104. Retrieved from http://jurnal.unej.ac.id/index.php/pancaran/article/view/665

Sarwa, I. N. (2010). Determinasi Potensi Akademik, Bakat Kinestetik, Dan Motivasi Berprestasi Terhadap Prestasi Belajar Karawitan Pada Mahasiswa Jurusan Karawitan Fakultas Seni Pertunjukkan Institut Seni Indonesia Denpasar. Jurnal Ilmiah Pendidikan Dan Pembelajaran, 7(1), 1-15. Retrieved from http://pasca.undiksha.ac.id/e-journal/index.php/jurnal_pp/article/view/23

Widhiarso, W. (2016). Sekilas Tentang Potensi Akademik. Retrieved June 7, 2018, from http://upap.psikologi.ugm.ac.id/sekilas-tentang-tes-potensi-akademik/ 